\title{
Identification of CTX-M Type ESBL E. coli from Sheep and Their Abattoir Environment Using Whole-Genome Sequencing
}

\author{
Nigatu Aklilu Atlaw ${ }^{1}{ }^{D}$, Shivaramu Keelara ${ }^{1}$, Maria Correa ${ }^{1}$, Derek Foster ${ }^{1}$, Wondwossen Gebreyes ${ }^{2} \mathbb{D}$, \\ Awa Aidara-Kane ${ }^{3}$, Lyndy Harden ${ }^{1}$, Siddhartha Thakur ${ }^{1}$ (D) and Paula J. Fedorka Cray ${ }^{1, *}$ \\ 1 Department of Population Health and Pathobiology, College of Veterinary Medicine, \\ North Carolina State University, Raleigh, NC 27607, USA; naatlaw@ncsu.edu (N.A.A.); \\ skeelar@ncsu.edu (S.K.); correa@ncsu.edu (M.C.); dmfoster@ncsu.edu (D.F.); lbharden@ncsu.edu (L.H.); \\ sthakur@ncsu.edu (S.T.) \\ 2 Department of Veterinary Preventive Medicine, The Ohio State University, 1920 Coffey Rd., \\ Columbus, OH 43210, USA; gebreyes.1@osu.edu \\ 3 Department Food Safety and Zoonoses, Foodborne Diseases, World Health Organization, \\ 1202 Geneva, Switzerland; aidarakanea@gmail.com \\ * Correspondence: pjcray@ncsu.edu
}

\section{check for} updates

Citation: Atlaw, N.A.; Keelara, S.; Correa, M.; Foster, D.; Gebreyes, W.; Aidara-Kane, A.; Harden, L.; Thakur, S.; Cray, P.J.F. Identification of CTX-M Type ESBL E. coli from Sheep and Their Abattoir Environment Using Whole-Genome Sequencing. Pathogens 2021, 10, 1480.

https://doi.org/

10.3390/pathogens 10111480

Academic Editor: Csaba Varga

Received: 22 September 2021

Accepted: 12 November 2021

Published: 14 November 2021

Publisher's Note: MDPI stays neutral with regard to jurisdictional claims in published maps and institutional affiliations.

Copyright: (c) 2021 by the authors. Licensee MDPI, Basel, Switzerland. This article is an open access article distributed under the terms and conditions of the Creative Commons Attribution (CC BY) license (https:/ / creativecommons.org/licenses/by/ $4.0 /)$.
Abstract: Widespread dissemination of extended-spectrum beta-lactamase (ESBL) Escherichia coli (E. coli) in animals, retail meats, and patients has been reported worldwide except for limited information on small ruminants. Our study focused on the genotypic characterization of ESBL E. coli from healthy sheep and their abattoir environment in North Carolina, USA. A total of 113 ESBL E. coli isolates from sheep $(n=65)$ and their abattoir environment $(n=48)$ were subjected to whole-genome sequencing (WGS). Bioinformatics tools were used to analyze the WGS data. Multiple CTX-Mtype beta-lactamase genes were detected, namely $b l a_{\mathrm{CTX}-\mathrm{M}-1}, b l a_{\mathrm{CTX}-\mathrm{M}-14}, b l a_{\mathrm{CTX}-\mathrm{M}-15}, b l a_{\mathrm{CTX}-\mathrm{M}-27}$, $b l a_{\mathrm{CTX}-\mathrm{M}-32}, b l a_{\mathrm{CTX}-\mathrm{M}-55}$, and $b l a_{\mathrm{CTX}-\mathrm{M}-65}$. Other beta-lactamase genes detected included $b l a_{\mathrm{CMY}-2 \text {, }}$

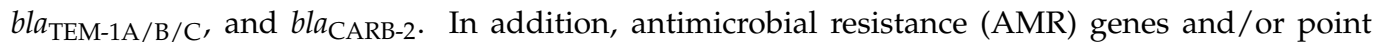
mutations that confer resistance to quinolones, aminoglycosides, phenicols, tetracyclines, macrolides, lincosamides, and folate-pathway antagonists were identified. The majority of the detected plasmids were shared between isolates from sheep and the abattoir environment. Sequence types were more clustered around seasonal sampling but dispersed across sample types. In conclusion, our study reported wide dissemination of ESBL E. coli in sheep and the abattoir environment and associated AMR genes, point mutations, and plasmids. This is the first comprehensive AMR and WGS report on ESBL E. coli from sheep and abattoir environments in the United States.

Keywords: abattoir environment; antimicrobial resistance; E. coli; ESBL; North Carolina; sheep; whole-genome sequencing

\section{Introduction}

Extended-spectrum beta-lactamase (ESBL)-producing Enterobacteriaceae are a serious public health threat and are increasing worldwide, including in the U.S. [1,2]. E. coli are commonly associated with gastro-intestinal, bloodstream, and urinary tract infections [2]. In addition, E. coli serves as a reservoir of transferrable antimicrobial resistance (AMR) genes, which can be passed to pathogenic organisms such as Salmonella spp. [3,4]. Other ESBL types such as SHV and TEM occurred prior to the emergence of CTX-M type ESBLs; however, CTX-M ESBLs became the leading type in clinical isolates in the early 2000s in the U.S. [5,6]. Later, community dissemination of CTX-M type ESBL E. coli, primarily due to bla $a_{\mathrm{CTXM}-15}$ and $b l a_{\mathrm{CTXM}-14}$, was reported among patients in the U.S. [7]. Additionally, CTX$M$ type ESBLs of food animal origin were first reported in fecal E. coli from sick and healthy dairy cattle in Ohio [8]. Nowadays, there are increasing reports of the dissemination of ESBL-producing E. coli in food animals, retail meat products, companion animals, and 
the environment in the U.S. and internationally, which in turn may increase public health risk [9-15].

Dissemination of ESBL E. coli in livestock farm-related environments such as soil, water, manure, air, dust, feed, etc., have recently been reviewed [16]. Although betalactamase genes including $b l a_{\mathrm{CTX}-\mathrm{M}-1}, b l a_{\mathrm{CTX}-\mathrm{M}-2}, b l a_{\mathrm{CTX}-\mathrm{M}-3}, b l a_{\mathrm{CTX}-\mathrm{M}-8}, b l a_{\mathrm{CTX}-\mathrm{M}-14}$ and $b l a_{\mathrm{CTX}-\mathrm{M}-15}, b l a_{\mathrm{SHV}}, b l a_{\mathrm{TEM}}$, and $b l a_{\mathrm{CMY}-2}$ were detected in feces of sheep and retail lamb in other parts of the world [10,17-20], there is no report available on AMR determinants of ESBL E. coli in small ruminants in the U.S. Therefore, to fill this gap in information, we conducted a study to detect and characterize AMR determinants using WGS in ESBL E. coli recovered from sheep and their abattoir environment in North Carolina.

\section{Results}

\subsection{AMR Genes and AMR-Associated Point Mutations Detected in ESBL E. coli}

Molecular characterization of AMR determinants (AMR genes, plasmids, and associated point mutations) of ESBL E. coli from sheep and their abattoir environment was conducted using whole-genome sequencing (WGS) data. A total of 113 ESBL E. coli isolates from sheep $(n=65)$ and their abattoir environment samples $(n=48)$ were included in this study, and results for antimicrobial susceptibility testing against a panel of 14 antimicrobials were obtained. The genotypic tests were $86 \%(1361 / 1582)$ concordant with the phenotypic tests for all tested ESBL E. coli isolates (Table 1). The results from 25 phenotypically resistant isolates did not demonstrate a mechanism of resistance, and a total of 196 tests of susceptible isolates carried AMR genes but were not resistant to the specific antimicrobial phenotypically (Table 1). Phenotypic AMR profiles along with the list of detected AMR genes and associated point mutations are shown in Table S1. These ESBL E. coli isolates carried a total of 47 different types of AMR genes that confer resistance to at least 10 classes of antimicrobials, 9 different types of AMR-associated point mutations, and 19 different plasmid types (Figure 1 and Table S2). Almost all isolates (98.2\%, 111/113) were resistant to at least three classes of antimicrobials, defined as multidrug-resistant (MDR) (Table S1).

Table 1. Comparison of the number of resistant ESBL E. coli isolates $(n=113)$ that displayed genotypic and phenotypic resistance to antimicrobials.

\begin{tabular}{|c|c|c|c|c|c|c|c|}
\hline \multirow{2}{*}{$\begin{array}{c}\text { Classes of } \\
\text { Antimicrobials }\end{array}$} & \multirow{2}{*}{$\begin{array}{l}\text { Tested } \\
\text { Drugs }\end{array}$} & \multirow{2}{*}{$\begin{array}{c}\text { Resistance } \\
\text { Break Point } \\
* *(\mu \mathrm{g} / \mathrm{mL})\end{array}$} & \multirow{2}{*}{$\begin{array}{c}\text { Number of } \\
\text { Isolates } \\
\text { Resistant (\%) } \\
\underset{* * *}{ }\end{array}$} & \multicolumn{2}{|c|}{ Phenotype: Resistant } & \multicolumn{2}{|c|}{ Phenotype: Susceptible * } \\
\hline & & & & $\begin{array}{l}\text { Genotype: } \\
\text { Resistant }\end{array}$ & $\begin{array}{c}\text { Genotype: } \\
\text { Susceptible }\end{array}$ & $\begin{array}{l}\text { Genotype: } \\
\text { Resistant }\end{array}$ & $\begin{array}{c}\text { Genotype: } \\
\text { Susceptible }\end{array}$ \\
\hline $\begin{array}{c}\text { Beta-lactam } \\
\text { combination agents }\end{array}$ & AUG2 & $\geq 32 / 16$ & $9(8.0)$ & 7 & 2 & 4 & 100 \\
\hline Penicillins & AMP & $\geq 32$ & $113(100.0)$ & 113 & 0 & 0 & 0 \\
\hline Macrolides & AZI & $\geq 32$ & $45(39.8)$ & 40 & 5 & 15 & 53 \\
\hline \multirow[t]{3}{*}{ Cephems } & FOX & $\geq 32$ & $9(8.0)$ & 7 & 2 & 4 & 100 \\
\hline & XNL & $\geq 8$ & 112 (99.1) & 112 & 0 & 1 & 0 \\
\hline & $\mathrm{AXO}$ & $\geq 4$ & $113(100.0)$ & 113 & 0 & 0 & 0 \\
\hline Phenicols & CHL & $\geq 32$ & $87(77.0)$ & 83 & 4 & 0 & 26 \\
\hline \multirow[t]{2}{*}{ Quinolones } & CIP & $\geq 1$ & $19(16.8 \%)$ & 19 & 0 & 50 & 44 \\
\hline & NAL & $\geq 32$ & $26(23.0)$ & 24 & 2 & 45 & 42 \\
\hline \multirow[t]{2}{*}{ Aminoglycosides } & GEN & $\geq 16$ & $21(18.6)$ & 21 & 0 & 67 & 25 \\
\hline & STR ** & $\geq 32$ & $85(75.2)$ & 84 & 1 & 4 & 24 \\
\hline Tetracyclines & TET & $\geq 16$ & $110(97.3)$ & 103 & 7 & 1 & 2 \\
\hline Folate pathway & FIS & $\geq 512$ & $93(82.3)$ & 93 & 0 & 1 & 19 \\
\hline antagonists & SXT & $\geq 4 / 76$ & $40(35.4)$ & 38 & 2 & 4 & 69 \\
\hline Total & & & & 857 & 25 & 196 & 504 \\
\hline
\end{tabular}

AUG2 = Amoxicillin/Clavulanic acid; AMP = Ampicillin; AZI = Azithromycin; FOX = Cefoxitin; XNL = Ceftiofur; AXO = Ceftriaxone; $\mathrm{CHL}=$ Chloramphenicol; CIP = Ciprofloxacin; NAL = Nalidixic Acid; GEN = Gentamicin; STR = Streptomycin; TET = Tetracycline; FIS = Sulfisoxazole; SXT $=$ Trimethoprim/Sulfamethoxazole. MIC = Minimum inhibitory concentration; ${ }^{*}$ For estimation of comparison parameters, the number of susceptible isolates included those with susceptible and intermediate MIC values; ${ }^{* *}$ Resistance break points for Streptomycin were based on the National Antimicrobial Resistance Monitoring System (NARMS)-established breakpoints for antimicrobial resistance. ${ }^{* * *}$ Number of isolates indicates number of phenotypically resistant isolates to the antimicrobial and percentage indicates proportion of isolates resistant to the antimicrobial among tested isolates. Total indicates the number of tests with a specific outcome. 


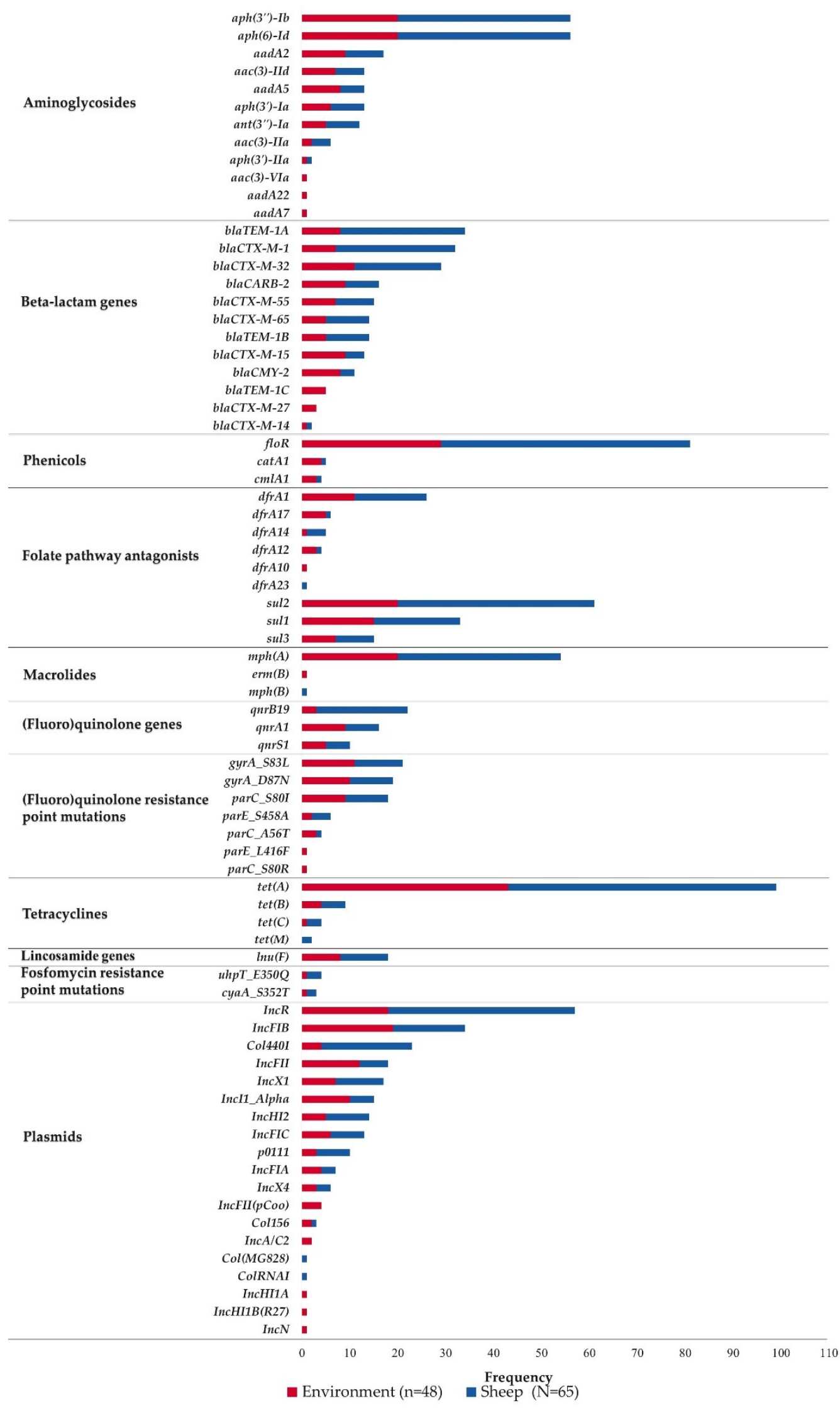

Figure 1. Frequency (\%) of AMR determinants detected in ESBL E. coli isolates $(n=113)$ among sample sources. 
Beta-lactamase genes: A total of 22 genotypic profiles of beta-lactamase resistanceconferring genes were detected, including individual or combinations of CTX-M, CARB, TEM, and AmpC type beta-lactamase genes (Table 2). About 96\% (108/113) of the ESBL E. coli isolates carried CTX-M-type ESBL encoding genes. Phenotypically, all study isolates were resistant to Ceftriaxone (MIC $\geq 4 \mu \mathrm{g} / \mathrm{mL}$ ), and Ampicillin (MIC $\geq 32 \mu \mathrm{g} / \mathrm{mL}$ ) and all except one isolate were resistant to Ceftiofur (MIC $\geq 8 \mu \mathrm{g} / \mathrm{mL}$ ). We report 7 unique CTXM-type ESBL genes from the 113 ESBL E. coli from sheep and their abattoir environment, namely bla $a_{\mathrm{CTX}-\mathrm{M}-1}(28.3 \%, 32 / 113)$, bla $_{\mathrm{CTX}-\mathrm{M}-14}(1.8 \%, 2 / 113), b l a_{\mathrm{CTX}-\mathrm{M}-15}(11.5 \%, 13 / 113)$, bla $a_{\mathrm{CTX}-\mathrm{M}-27}(2.7 \%, 3 / 113)$, bla $_{\mathrm{CTX}-\mathrm{M}-32}(25.7 \%, 29 / 113), b l a_{\mathrm{CTX}-\mathrm{M}-55}(13.3 \%, 15 / 113)$ and bla CTX-M-65 $(12.4 \%, 14 / 113)$ (Figure 1 and Table S2). Other beta-lactamase genes detected were $b l a_{\mathrm{TEM}-1}(46.9 \%, 53 / 113)$, bla $_{\mathrm{CARB}-2}(14.2 \%, 16 / 113)$ and the AmpC beta-lactamase gene, $b l a_{\mathrm{CMY}-2}(9.7 \%, 11 / 113)$ (Figure 1 and Table S2). Three types of $b l a_{\mathrm{TEM}-1}$ genes were detected: $b l a_{\text {TEM-1A }}(30.1 \%, 34 / 113), b l a_{\text {TEM-1B }}(12.4 \%, 14 / 113)$ and $b l a_{\text {TEM-1C }}(4.4 \%, 5 / 113)$. None of the CTX-M type ESBL genes were found in five isolates (Table 2). Of these, four carried a combination of bla $\mathrm{CMY}-2$ and $b l a_{\mathrm{TEM}-1 \mathrm{C}}$, and one carried $b l a_{\mathrm{CMY}-2}$ without additional beta-lactamase genes.

The five most frequent beta-lactam genes found together or alone were $b l a_{\mathrm{CTX}-\mathrm{M}-1}$ and bla $a_{\text {TEM-1A }}(21.2 \%, 24 / 113)$, bla $_{\text {CTX-M-32 }}$ and bla $a_{\text {CARB-2 }}(13.3 \%, 15 / 113), b l a_{\text {CTX-M-32 }}(11.5 \%$, $13 / 113), b l a_{\mathrm{CTX}-\mathrm{M}-15}(8.8 \%, 10 / 113)$ and bla $_{\mathrm{CTX}-\mathrm{M}-55}(8.8 \%, 10 / 113)$ (Table 2). The remaining mechanisms of beta-lactam resistance are presented in Table 2. All beta-lactamase genes reported had 100\% length coverage and 100\% identity to previously published beta-lactamase genes. Seven out of 11 isolates that carried the bla $a_{\mathrm{CMY}-2}$ gene were resistant to Cefoxitin and Amoxicillin/Clavulanic acid (Figure 2). The rest of the four isolates carried $b l a_{\mathrm{CMY}-2}$ with $b l a_{\mathrm{TEM}-1 \mathrm{C}}$; however, they were susceptible to these antimicrobials. All Amoxicillin/Clavulanic acid-resistant ESBL E. coli isolates (MIC $\geq 32 / 16 \mu \mathrm{g} / \mathrm{mL}$ ) were also resistant to Cefoxitin (MIC $\geq 32)(n=9)$. Of these, the majority $(n=6)$ carried a combination of $b l a_{\mathrm{CTX}-\mathrm{M}-1}, b l a_{\mathrm{CMY}-2}$ and $b l a_{\mathrm{TEM}-1 \mathrm{~A}}$, while others carried $b l a_{\mathrm{CTX}-\mathrm{M}-1}$ and $b l a_{\mathrm{TEM}-1 \mathrm{~A}}(\mathrm{n}=1)$, $b l a_{\mathrm{CTX}-\mathrm{M}-32}$ and $b l a_{\mathrm{CARB}-2}(\mathrm{n}=1)$ or $b l a_{\mathrm{CMY}-2}(\mathrm{n}=1)$ alone. The isolate with $b l a_{\mathrm{CMY}-2}$ alone as the beta-lactamase gene was susceptible to Ceftiofur $(\mathrm{MIC}=4 \mu \mathrm{g} / \mathrm{mL})$ and had the lowest MIC value for Ceftriaxone $(8 \mu \mathrm{g} / \mathrm{mL})$ (Table S1 and Figure 2). The list of and percent detection of known AMR genes, including other classes of antimicrobials, AMR-associated point mutations, and plasmids are shown in Table S2.

Aminoglycosides: Phenotypic aminoglycoside-resistant ESBL E. coli $(\mathrm{n}=87)$ isolates, as determined by resistance to Gentamicin (MIC $\geq 16 \mu \mathrm{g} / \mathrm{mL}$ ) and/or Streptomycin (MIC $\geq 32 \mu \mathrm{g} / \mathrm{mL}$ ), carried at least one gene known to confer this resistance, except in one isolate where the resistance mechanism was not identified (Table 1). Aminoglycosideresistant isolates carried a total of 23 different genotypic profiles; the top three profiles were $\operatorname{aph}\left(3^{\prime \prime}\right)-I b$ (or strA) and $\operatorname{aph}(6)-I d$ (or StrB) (31.0\%, 35/113), aadA2 alone (12.4\%, 14/113), and aadA5, aph(3")-Ib and aph(6)-Id (8.0\%, 9/113) (Table S3).

Macrolides: Most (40/45) of the Azithromycin (a macrolide)-resistant isolates (MIC $\geq 32 \mu \mathrm{g} / \mathrm{mL}$ ) carried $m p h(A)$; however, a known macrolide resistance mechanism was not detected in five isolates (Table 1). One Azithromycin-resistant isolate carried an additional mechanism, erm (B) (Table S3). However, several ESBL E. coli isolates that carried either $m p h(A)$ or $m p h(B)(n=15)$ were phenotypically susceptible to Azithromycin (Table 1).

Phenicols: Chloramphenicol-resistant ESBL E. coli isolates $(\mathrm{n}=87, \mathrm{MIC} \geq 32 \mu \mathrm{g} / \mathrm{mL})$ carried either floR $(\mathrm{n}=65.5 \%, 74 / 113)$ or cat $A 1(1.8 \%, 2 / 113)$ or combinations of floR and $c m l A 1(3.5 \%, 4 / 113)$ or floR and cat A1 (2.7\%, 3/113) (Table S3). Genes that conferred phenicol resistance were not detected in four phenotypically Chloramphenicol-resistant ESBL E. coli isolates (Table 1). 
Table 2. Number and percentage of beta-lactamase genes in ESBL E. coli isolates $(\mathrm{n}=113)$ from sheep and abattoir environment and number of isolates carrying these genes among sample types and seasons.

\begin{tabular}{|c|c|c|c|c|c|c|c|c|c|c|c|c|c|}
\hline \multirow{2}{*}{$\begin{array}{l}\text { Profile of Beta-Lactamase } \\
\text { Genes }\end{array}$} & \multirow{2}{*}{$\begin{array}{l}\text { No. } \\
(\%)\end{array}$} & \multicolumn{4}{|c|}{ Sheep Samples $(\mathbf{N}=65)$} & \multicolumn{4}{|c|}{$\begin{array}{l}\text { Environmental Samples } \\
\qquad(\mathrm{N}=48)\end{array}$} & \multicolumn{4}{|c|}{ Seasons } \\
\hline & & $\begin{array}{l}\text { CS } \\
10\end{array}$ & $\begin{array}{l}\mathrm{CC} \\
20\end{array}$ & $\begin{array}{l}\text { SF } \\
28\end{array}$ & $\begin{array}{c}\text { RAF } \\
7\end{array}$ & $\begin{array}{l}\text { SS } \\
10\end{array}$ & $\begin{array}{l}\text { LS } \\
21\end{array}$ & $\begin{array}{c}\text { FS } \\
8\end{array}$ & $\begin{array}{c}\text { WS } \\
9\end{array}$ & $\begin{array}{l}\text { SP } \\
44\end{array}$ & $\begin{array}{l}\text { SU } \\
27\end{array}$ & $\begin{array}{l}\text { FA } \\
15\end{array}$ & $\begin{array}{l}\text { WI } \\
27\end{array}$ \\
\hline$b l a_{\mathrm{CTX}-\mathrm{M}-1}, b l a_{\mathrm{TEM}-1 \mathrm{~A}}$ & $\begin{array}{c}24 \\
(21.2)\end{array}$ & 4 & 5 & 10 & 1 & - & 1 & 1 & 2 & 14 & 9 & 1 & - \\
\hline$b l a_{\mathrm{CTX}-\mathrm{M}-32}, b l a_{\mathrm{CARB}-2}$ & $\begin{array}{c}15 \\
(13.3)\end{array}$ & 1 & 3 & 3 & - & - & 5 & 2 & 1 & 10 & 2 & - & 3 \\
\hline$b l a_{\mathrm{CTX}-\mathrm{M}-32}$ & $\begin{array}{c}13 \\
(11.5)\end{array}$ & - & 1 & 7 & 2 & 1 & - & 2 & - & 5 & 2 & 2 & 4 \\
\hline$b l a_{\mathrm{CTX}-\mathrm{M}-15}$ & $\begin{array}{c}10 \\
(8.8)\end{array}$ & - & 3 & 1 & - & - & 5 & - & 1 & 9 & - & - & 1 \\
\hline$b l a_{\mathrm{CTX}-\mathrm{M}-55}$ & $\begin{array}{c}10 \\
(8.8)\end{array}$ & 2 & 1 & 1 & - & 2 & 3 & 1 & - & - & 1 & 2 & 7 \\
\hline$b l a_{\mathrm{CTX}-\mathrm{M}-65}$ & $\begin{array}{c}7 \\
(6.2)\end{array}$ & 1 & - & 2 & 1 & 2 & - & - & 1 & - & 6 & - & 1 \\
\hline$b l a_{\mathrm{CTX}-\mathrm{M}-1}, b l a_{\mathrm{CMY}-2}, b l a_{\mathrm{TEM}-1 \mathrm{~A}}$ & $\begin{array}{c}6 \\
(5.3)\end{array}$ & - & 1 & 1 & 1 & - & 1 & 1 & 1 & - & - & 2 & 4 \\
\hline$b l a_{\mathrm{CTX}-\mathrm{M}-55}, b l a_{\mathrm{TEM}-1 \mathrm{~B}}$ & $\begin{array}{c}5 \\
(4.4)\end{array}$ & 1 & 1 & 2 & - & 1 & - & - & - & - & 4 & - & 1 \\
\hline$b l a_{\mathrm{CMY}-2}, b l a_{\mathrm{TEM}-1 \mathrm{C}}$ & $\begin{array}{c}4 \\
(3.5)\end{array}$ & - & - & - & - & - & 4 & - & - & 4 & - & - & - \\
\hline$b^{b l a} a_{\mathrm{CTX}-\mathrm{M}-65}$, bla & $\begin{array}{c}4 \\
(3.5)\end{array}$ & - & 1 & 1 & 1 & 1 & - & - & - & - & - & 4 & - \\
\hline$b l a_{\mathrm{CTX}-\mathrm{M}-65}, b l a_{\mathrm{TEM}-1 \mathrm{~B}}$ & $\begin{array}{c}3 \\
(2.7)\end{array}$ & 1 & - & - & 1 & 1 & - & - & - & 1 & - & - & 2 \\
\hline$b l a_{\mathrm{CTX}-\mathrm{M}-15}, b l a_{\mathrm{TEM}-1 \mathrm{~B}}$ & $\begin{array}{c}2 \\
(1.8)\end{array}$ & - & - & - & - & 2 & - & - & - & - & - & 1 & 1 \\
\hline$b l a_{\mathrm{CMY}-2}$ & $\begin{array}{c}1 \\
(0.9)\end{array}$ & - & - & - & - & - & 1 & - & - & - & 1 & - & - \\
\hline$b l a_{\mathrm{CTX}-\mathrm{M}-1}$ & $\begin{array}{c}1 \\
(0.9)\end{array}$ & - & 1 & - & - & - & - & - & - & 1 & - & - & - \\
\hline$b l a_{\mathrm{CTX}-\mathrm{M}-1}, b l a_{\mathrm{TEM}-1 \mathrm{~B}}$ & $\begin{array}{c}1 \\
(0.9)\end{array}$ & - & 1 & - & - & - & - & - & - & - & 1 & - & - \\
\hline$b l a_{\mathrm{CTX}-\mathrm{M}-14}$ & $\begin{array}{c}1 \\
(0.9)\end{array}$ & - & - & - & - & - & - & - & 1 & - & 1 & - & - \\
\hline$b l a_{\mathrm{CTX}-\mathrm{M}-14}, b l a_{\mathrm{TEM}-1 \mathrm{~B}}$ & $\begin{array}{c}1 \\
(0.9)\end{array}$ & - & 1 & - & - & - & - & - & - & - & - & 1 & - \\
\hline$b l a_{\mathrm{CTX}-\mathrm{M}-15}, b l a_{\mathrm{TEM}-1 \mathrm{C}}$ & $\begin{array}{c}1 \\
(0.9)\end{array}$ & - & - & - & - & - & - & - & 1 & - & - & - & 1 \\
\hline$b l a_{\mathrm{CTX}}-\mathrm{M}-27$ & $\begin{array}{c}1 \\
(0.9)\end{array}$ & - & - & - & - & - & - & 1 & - & - & - & - & 1 \\
\hline$b l a_{\mathrm{CTX}-\mathrm{M}-27}, b l a_{\mathrm{CARB}-2}$ & $\begin{array}{c}1 \\
(0.9)\end{array}$ & - & - & - & - & - & - & - & 1 & - & - & 1 & - \\
\hline$b l a_{\mathrm{CTX}-\mathrm{M}-27}, b l a_{\mathrm{TEM}-1 \mathrm{~B}}$ & $\begin{array}{c}1 \\
(0.9)\end{array}$ & - & - & - & - & - & 1 & - & - & - & - & 1 & - \\
\hline$b l a_{\mathrm{CTX}-\mathrm{M}-32}, b l a_{\mathrm{TEM}-1 \mathrm{~B}}$ & $\begin{array}{c}1 \\
(0.9)\end{array}$ & - & 1 & - & - & - & - & - & - & - & - & - & 1 \\
\hline
\end{tabular}

$\mathrm{CC}=$ Carcass swabs, $\mathrm{CS}=$ Cecal content, $\mathrm{SF}=$ Sheep feces, $\mathrm{RAF}=$ Resting area feces, $\mathrm{SS}=$ Soil sample, $\mathrm{LS}=$ Lairage swab, FS = Feed sample, $\mathrm{WS}=$ Water sample, $\mathrm{SP}=$ Spring, $\mathrm{SU}=$ Summer, $\mathrm{FA}=$ Fall, $\mathrm{WI}=$ Winter 


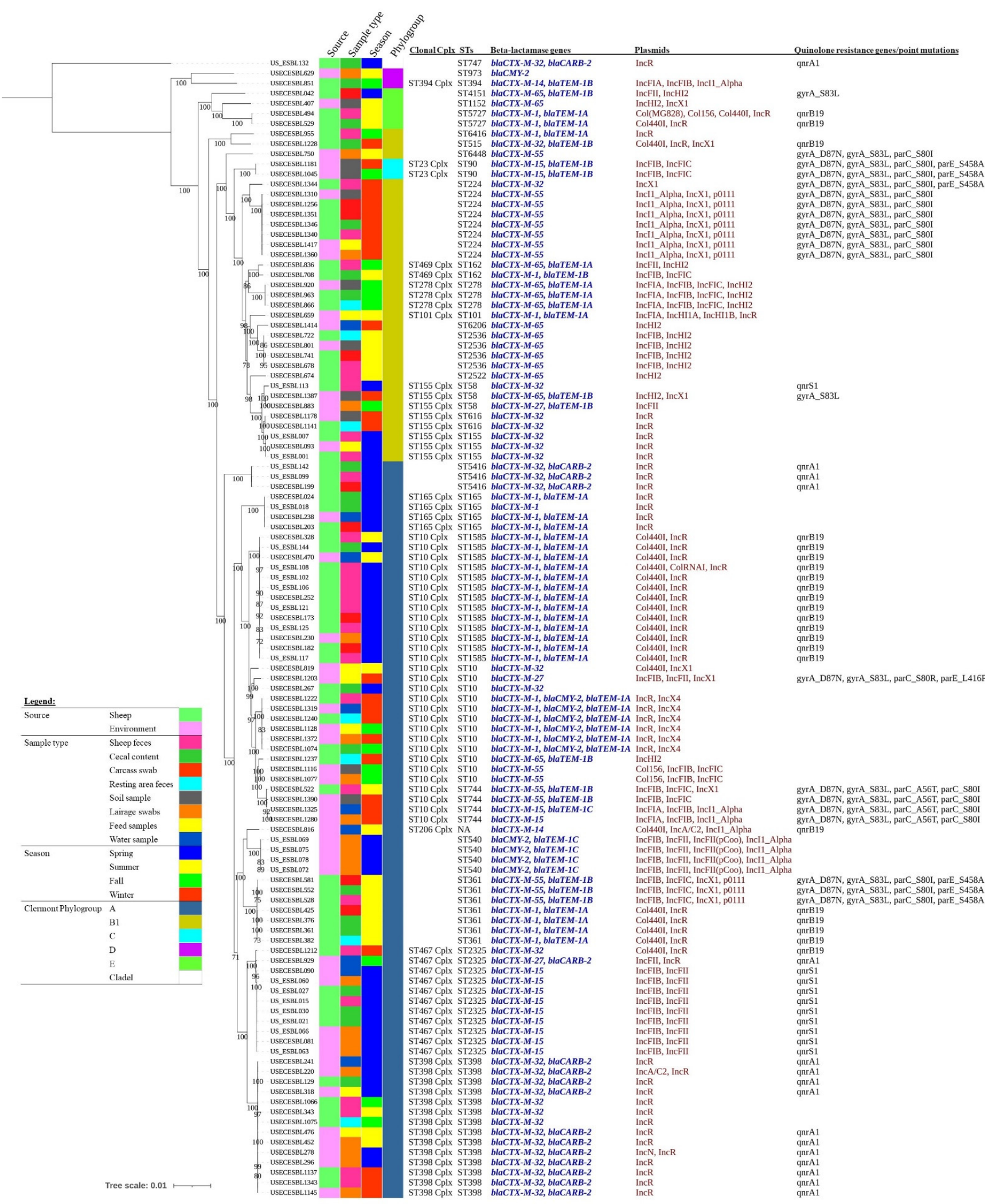

Figure 2. Midpoint rooted phylogenetic tree constructed based on maximum-likelihood of core-genome alignment from 113 ESBL E. coli. The alignment was built using Roary version 3.13.0. The ML phylogenetic tree was made using RaxMLGUI2.0 with the best fitting model GTR + I + G. Visualization and annotation was carried out through iTOL version 6.3 (https://itol.embl.de/itol.cgi; accessed on 19 July 2021). Bootstrap values between $70 \%$ and $100 \%$ are shown. The total number of core genes was 3049 and the total number of alignment sites was 2988599. Cplx = complex; STs = Sequence types. 
Quinolones/Fluoroquinolones: All ESBL E. coli isolates phenotypically resistant to Ciprofloxacin, a fluoroquinolone $(\mathrm{n}=19$, MIC $\geq 4 \mu \mathrm{g} / \mathrm{mL}$ ), carried at least three substitutions: two substitutions at quinolone resistance-determining regions (QRDR) of the gene for DNA gyrase (gyrA_D87N and gyrA_S83L) and all except one had additional substitution at topoisomerase IV (parC_S80I) and the remaining one isolate at parC_S80R). Nearly half of these isolates (11/19) carried a fourth substitution at topoisomerase IV (either parC_A56T $(\mathrm{n}=4)$, parE_S458A $(\mathrm{n}=6)$ or parE_L416F $(\mathrm{n}=1)$ ) (Tables S1 and S3). Two isolates (USECESBL042 and 1387) with a single substitution at the gene for DNA gyrase, gyrA_S83L, were resistant to Nalidixic acid but not resistant to Ciprofloxacin (Table $\mathrm{S1}$ ). ESBL E. coli isolates carried plasmid-mediated quinolone resistance (PMQR) genes, namely qnrA1 (14.2\%, 16/113), qnrB19 (19.5\%, 22/113), and qnrS1 (8.8\%, 10/113), but none of these isolates had quinolone resistance-associated point mutations (Table S1 and Figure 2). Among these isolates with PMQR, only three isolates which harbored qnrB19 were resistant to Nalidixic acid; the rest of the isolates were not resistant to both Nalidixic acid and Ciprofloxacin. Two Nalidixic acid-resistant isolates did not carry any known quinolone resistance determinants (Table S1 and Figure 2).

Folate pathway antagonists: Among all tested isolates, nearly 40\% (45/113) carried sul2 and 22.1\% (25/113) carried sul1 and $d f r A 1$ (Table S3). The remaining isolates exhibited 12 different genotypic profiles of resistance against folate-pathway antagonists. Among isolates resistant to folate-pathway antagonists (93/113), all Trimethoprim/Sulfamethoxazole (MIC $\geq 4 / 76 \mu \mathrm{g} / \mathrm{mL}$ )-resistant isolates $(40 / 113)$ were also resistant to Sulfisoxazole (MIC $\geq 512 \mu \mathrm{g} / \mathrm{mL}$ ) (Tables 1 and S1). Sul-type genes were not detected in two Sulfisoxazole-resistant isolates and an isolate susceptible to Sulfisoxazole and Sulfamethoxazole-Trimethoprim carried both sul1 and $d f r A 1$ genes. Similarly, $d f r A-$ type genes were not detected in two Sulfamethoxazole-Trimethoprim-resistant isolates. In contrast, $d f r A 1$ was detected in four isolates that were phenotypically categorized as sensitive to Sulfamethoxazole-Trimethoprim (Table S1).

Tetracyclines: From a total of 110 Tetracycline-resistant (MIC $\geq 16$ ) ESBL E. coli, 103 $(93.6 \%)$ carried at least one gene known to confer Tetracycline resistance (Table 1$)$. These isolates carried either tet $(A)(78.8 \%, 89 / 113)$, tet $(B)(3.5 \%, 4 / 113)$, tet $(A)$ and tet $(B)(4.4 \%$, $5 / 113), \operatorname{tet}(A)$ and $\operatorname{tet}(C)(3.5 \%, 4 / 113)$ or $\operatorname{tet}(A)$ and $\operatorname{tet}(M)(0.9 \%, 1 / 113)$ (Table S3). One isolate that carried tet $(M)$ was phenotypically sensitive to Tetracycline. Seven Tetracyclineresistant ESBL E. coli isolates did not carry any of the above Tetracycline-conferring genes (Tables 1 and S1).

Lincosamides and Fosfomycin: Lincosamide nucleotidyltransferase coding gene, $\operatorname{Inu}(F)$, which confers resistance to lincomycin was detected in some ESBL isolates (15.9\%, 18/113) (Figure 1, Tables S2 and S1). In addition, Fosfomycin resistance-conferring regulatory gene mutations in either cyaA_S352T $(\mathrm{n}=2)$, uhpT_E350Q $(\mathrm{n}=3)$, or both $(\mathrm{n}=1)$ were detected in ESBL E. coli isolates in this study (Table S1 and Table S3). However, the ESBL E. coli isolates were not evaluated for phenotypic susceptibility to Lincosamides and Fosfomycin.

\subsection{AMR Determinants among Sample Types and Seasons}

Most of the AMR gene types (37/47) and point mutation types (7/9) detected in this study were carried by ESBL E. coli isolates from both sheep and environment sources

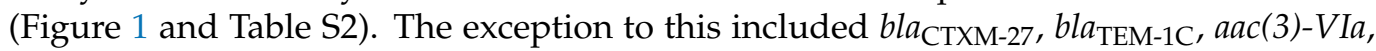
aadA22, aadA7, dfrA10, ermB, and two substitutions at QRDR (parC_S80R and parE_L416F). These genes and point mutations were not detected in isolates from sheep samples. On the other hand, $\operatorname{dfr} A 23, m p h B$, and tet $(M)$ were not detected in isolates from the environmental samples. Carriage of AMR determinants differed between seasons, and only about $44.5 \%$ (21/47) AMR gene types and 14.3\% (1/7) of the types of substitutions at QRDR were detected in all seasons of the study. Of these, 12 types of AMR genes (bla $a_{\mathrm{CTXM}-1}, b l a_{\mathrm{CTXM}-32 \text {, }}$ $b l a_{\mathrm{TEM}-1 \mathrm{~A}}, \operatorname{aph}\left(3^{\prime \prime}\right)-I b, a p h(6)-I d$, floR, $m p h A, d f r A 1, \operatorname{sul1}, \operatorname{sul2}, \operatorname{tet}(A)$ and $\left.\operatorname{tet}(B)\right)$ were detected in two or more isolates per season (Figure 1 and Table S2). Among beta-lactamase genes, all 
ESBL E. coli isolates from carcass swabs $(\mathrm{n}=10)$ carried CTX-M type ESBL genes including bla $a_{\text {CTX-M-1 }}(\mathrm{n}=4), b l a_{\mathrm{CTX}-\mathrm{M}-55}(\mathrm{n}=3), \operatorname{bla}_{\mathrm{CTX}-\mathrm{M}-65}(\mathrm{n}=2)$ and bla $a_{\mathrm{CTX}-\mathrm{M}-32}(\mathrm{n}=1)$ (Table 2). These isolates were recovered in spring $(n=5)$, summer $(n=3)$, and winter $(n=2)$ seasons (Figure 2).

\subsection{Characterization of Plasmids in ESBL E. coli from Sheep and Abattoir Environment}

Plasmids (19 different types) were detected in 96\% (109/113) of the ESBL E. coli isolates (Figure 2). The most common types of plasmids detected were IncR (50.4\%, 57/113), IncFIB (30.1\%, 34/113), and Col440I (20.4\%, 23/113) (Figure 1 and Table S2). The majority of the isolates carried more than one plasmid. The top five plasmid profiles(s) detected in ESBL E. coli isolates were IncR alone $(23.0 \%, 26 / 113)$, Col440I and IncR (15.9\%, 18/113), IncFIB and IncFII (8.0\%, 9/113), IncI1_Alpha, IncX1 and p0111 (6.2\%, 7/113), and IncR and IncX4 $(5.3 \%, 6 / 113)$ (data not shown). Isolates shared all plasmid types from both sheep and environment sources, except that IncA/C, IncFIIpCoo, IncHI1A, IncHI1B, and IncN were detected only in isolates from the abattoir environment, and Col(MG828) and ColRNAI were detected only in isolates from sheep samples. Carriage of plasmids varied between seasons, and only four types of plasmids (IncFIB, IncR IncHI2, and IncI1-Alpha) were detected in all seasons of the study (Figure 1 and Table S2).

\subsection{Sequence Types and Phylogenetic Analysis of ESBL E. coli Isolates}

ClermonTyping of 113 ESBL E. coli isolates showed that most of the ESBL E. coli isolates belonged to phylogroup A (73/113, 64.6\%) and phylogroup B1 (31/113, 27.4\%). The remaining nine isolates were assigned to phylogroup $C$ and D (two isolates each), phylogroup E (four isolates), and CladeI (one isolate). Distributions of phylogroups of ESBL E. coli isolates among the different sample types and seasons are shown in Figure 3.

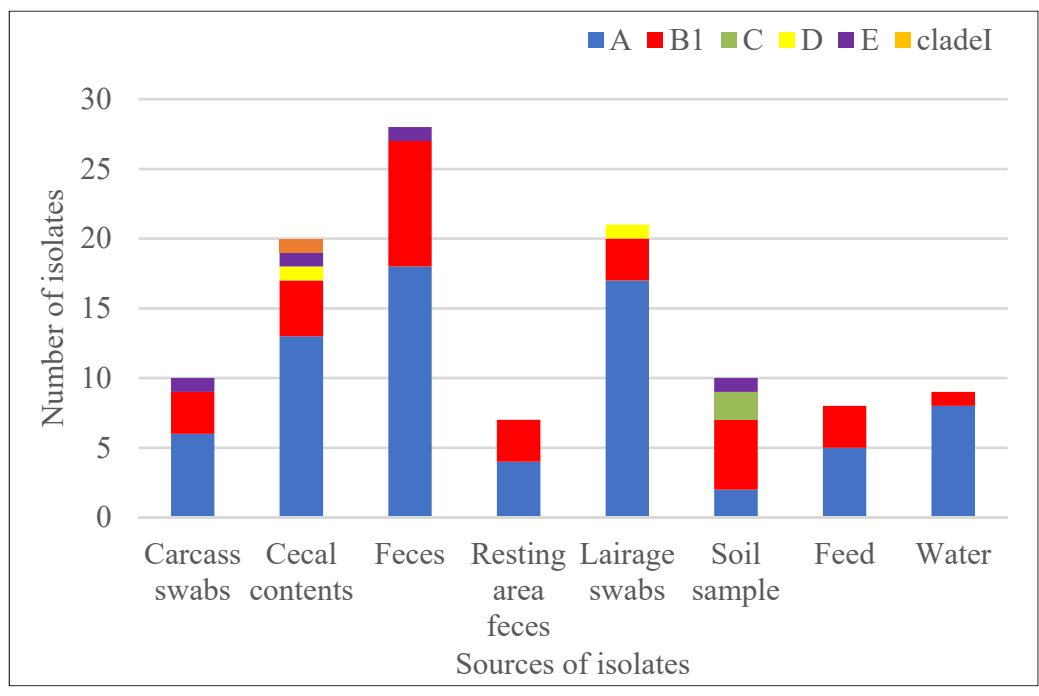

(a)

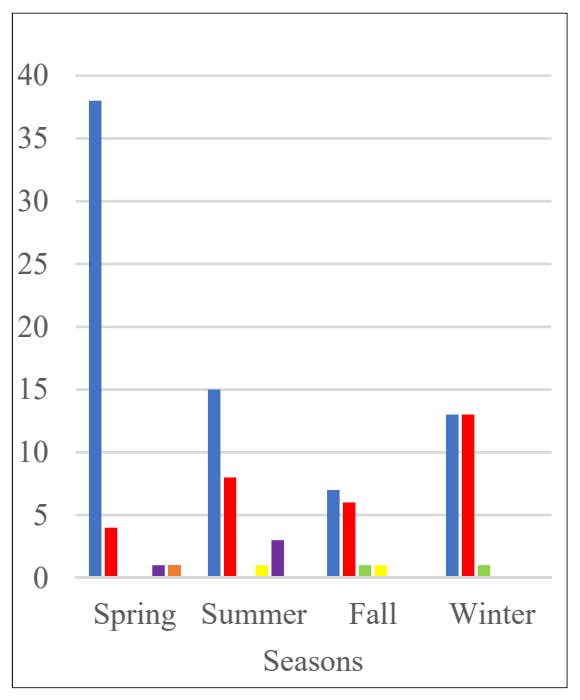

(b)

Figure 3. Type and number of phylogroups of ESBL E. coli recovered from the different sample types (a) and among the four seasons (b). Phylogroups were determined using Clermont Typing. Phylogroups are indicated with different colors: blue for phylogroup A, red for phylogroup B1, light green for phylogroup C, yellow for phylogroup D, purple for phylogroup E, and orange for cladeI. (a) indicates that phylogroup A and B1 were commonly found in all sample types, phylogroup C was found only in soil samples, phylogroup D was found in cecal content and lairage swab, phylogroup E was found in cecal content, sheep feces, carcass swab and soil samples and CladeI was found in cecal content. (b) indicates number of the different phylogroups recovered in the four seasons. Phylogroups A and B1 were found in all seasons. Phylogroups C, D, and $\mathrm{E}$ were each detected in two seasons. CladeI was found only in spring season. 
A total of 38 different serotypes were detected, with the most predominant ones being O8:H20 (12.4\%), -:H32 (11.5\%), O9:H30 (9.7\%), O10:H25 (8.0\%) and -:H23 (6.2\%). Twelve out of the 38 different serotypes were detected both in ESBL E. coli from sheep and the abattoir environment and included O10:H25, O100:H32, O178:H7, O32:H10, O8:H20, O8:H9, O9:H30, -:H23, -:H26, -:H28, -:H32 and -:H34 (Table S1).

Twenty-nine different sequence types (STs) were detected from all tested ESBL E. coli isolates, and 12 of the STs were detected in isolates from both sheep and abattoir environment samples. The top ten common sequence types, accounting for $72 \%$ of the isolates, were ST398 (14/113), ST1585 (13/113), ST10 (12/113), ST2325 (11/113), ST224 (8/113), ST361 (7/113) and ST165, ST540, ST744 and ST2536 (4/113 each). ST for one isolate (Isolate ID: USECESBL816, SRR11347457) was not identified by the MLST database. Twelve out of the 29 STs (ST398, ST585, ST10, ST2325, ST224, ST165, ST744, ST2536, ST58, ST155, ST278, and ST616) were detected in ESBL E. coli isolates from both sheep and the abattoir environment $(81 / 113,71.7 \%)$. Fifteen unique STs of ESBL E. coli were detected in sheep feces, followed by cecal content (14 STs), abattoir resting area feces (12 STs), and lairage swab (10 STs), and the least diversified were isolates from feed samples (5 STs) (Figure 2). ST398 and ST10 were detected in all seasons of the study duration, while two STs (ST58 and ST2325) were detected in three seasons (fall, spring, and winter), and the majority $(21 / 29)$ of the unique STs were detected only in a season. However, 14 unique STs of ESBL E. coli were detected in summer, followed by spring (11 STs), winter (10 STs), and fall (9 STs) (Figure 2). The core-genome phylogenetic analyses of the ESBL E. coli isolates revealed that sequence types of isolates were more clustered based on season than based on source or type of samples (Figure 2).

\section{Discussion}

To our knowledge, this is the first report of molecular characterization of AMR determinants in ESBL E. coli from sheep and their abattoir environment in the U.S. The isolates were obtained from a year-round serial cross-sectional study between March 2019 and February 2020 in North Carolina. In this study, 95.6\% (108/113) of the phenotypically confirmed ESBL E. coli carried CTX-M-type beta-lactamase genes as mechanisms of ESBL production. The most predominant beta-lactamase genes detected in our study were bla $_{\mathrm{CTX}-\mathrm{M}-1}$ and $b l a_{\mathrm{CTX}-\mathrm{M}-32}$ followed by $b_{\text {CTX-M-55 }}, b l a_{\mathrm{CTX}-\mathrm{M}-65}, b l a_{\mathrm{CTX}-\mathrm{M}-15}, b l a_{\mathrm{CTX}-\mathrm{M}-27}$, and $b l a_{\text {CTX-M-14. }}$. In the U.S., bla $a_{\text {CTX-M-1 }}$ was reported as the predominant CTX-M-type ESBL gene in E. coli recovered from environmental samples from dairy farms, livestock auction markets, and equine facilities [21]. However, $b l a_{\mathrm{CTX}-\mathrm{M}-15}$ is the predominant and widely disseminated ESBL gene carried by ESBL E. coli from dairy cattle farms in other locations and human urinary tract infections in the U.S. [7,21-23]. In cattle and humans, bla $a_{\mathrm{CTX}-\mathrm{M}-27}$ and $b l a_{\mathrm{CTX}-\mathrm{M}-14}$ were also commonly reported in these studies. We detected $b l a_{\mathrm{CTX}-\mathrm{M}-15}$ in ESBL E. coli from 13 isolates recovered from cecal contents, sheep feces, lairage swabs, soil sample, and water, while $b l a_{\mathrm{CTX}-\mathrm{M}-14}$ and $b l a_{\mathrm{CTX}-\mathrm{M}-27}$ were less frequent and detected in only two and three isolates, respectively. Six ESBL E. coli isolates (O100:H32, ST10) recovered from both sheep and the abattoir environment in our study carried a combination of three beta-lactamase genes: $b l a_{\mathrm{CTX}-\mathrm{M}-1}$ (broad-spectrum ESBL gene), $b l a_{\mathrm{TEM}-1 \mathrm{~A}}$ (narrow spectrum), and bla $a_{\mathrm{CMY}-2}$ (AmpC type beta-lactamase gene). Such ESBL E.coli isolates were previously termed as mixed ESBL/AmpC phenotype [24]. CTX-M-type and SHV-type ESBL genes were found to coexist in ESBL E. coli from sheep meat in China [11]. bla $a_{\mathrm{SHV}}$, $b l a_{\mathrm{OXA}}$, and $a a c(6)-\mathrm{Ib}-c r$ type beta-lactamase genes were not detected from both sources in our study, which may restate the current predominance of CTX-M and TEM-type ESBLs in E. coli [25]. A combination of CTX-M and TEM type beta-lactamase genes had been reported in ESBL E. coli isolates from sheep in Turkey [19], while Lui et al. (2016) reported up to eight different beta-lactamase genes in ESBL E. coli from a dog with severe urinary tract infection in the U.S., including four different CTX-M-types and four other types (TEM, CMY, SHV, and aac $\left.\left(6^{\prime}\right)-\mathrm{Ib}-\mathrm{cr}\right)$ of beta-lactamase genes. 
In this study, five ESBL E. coli isolates carried the AmpC type beta-lactamase gene, bla $a_{\mathrm{CMY}-2}$ with $b l a_{\mathrm{TEM}-1 \mathrm{C}}(\mathrm{n}=4)$ or alone $(\mathrm{n}=1)$ and did not carry the ESBL gene. The genes known for ESBL production were not detected in these isolates. This observation could be due to other undetected genes or false-positive results in the determination of ESBL status at the screening phase, as previously observed in other studies [26,27]. The other two ESBL producer isolates were resistant to Cefoxitin and Amoxicillin/Clavulanic acid in the absence of $b l a_{\mathrm{CMY}-2}$. These isolates carried ESBL genes bla $a_{\mathrm{CTX}-\mathrm{M}-1}$ and bla $a_{\mathrm{CTX}-\mathrm{M}-14}$ combined with $b l a_{\mathrm{TEM}-1 \mathrm{~A}}$ and $b l a_{\mathrm{CARB}-2}$, respectively. This discrepancy of phenotypic and genotypic results could be the lack of expression of genes in the genotypically predicted resistant but phenotypically susceptible isolates to infer resistance, as previously noticed [28].

This is the first report of multiple beta-lactamase genes in ESBL E. coli from sheep in the United States. Wide dissemination of multiple types of beta-lactamase genes was previously reported from cattle and retail meats excluding lamb and goat in the U.S. [8,9,23] and companion animals (dogs and cats) [12]. From the U.S. public health sector, the most commonly reported CTX-M type genes in ESBL E. coli were bla $a_{\mathrm{CTX}-\mathrm{M}-15}$ and $b l a_{\mathrm{CTX}-\mathrm{M}-14}[5,7,22,29]$. These studies also reported multiple types of beta-lactamase genes in patients with urinary tract and bloodstream infections and pneumonia, including bla $a_{\mathrm{CTX}-\mathrm{M}-3}, b l a_{\mathrm{CTX}-\mathrm{M}-16}, b l a_{\mathrm{CTX}-\mathrm{M}-27}, b_{\mathrm{CTX}-\mathrm{M}-107}, b l a_{\mathrm{SHV}-2}, b l a_{\mathrm{SHV}-5}, b l a_{\mathrm{SHV}-12}, b l a_{\mathrm{TEM}-1}$, and

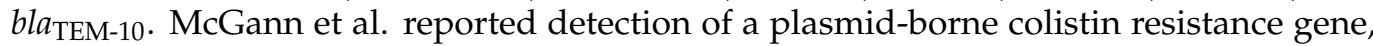

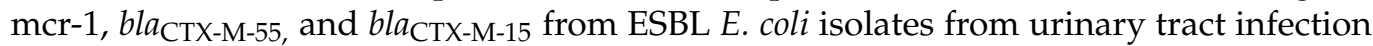
in the U.S. [30]. In a study conducted on ESBL E. coli from lamb meat in Brazil, MDR and potentially pathogenic isolates harboring $b l a_{\mathrm{CTX}-\mathrm{M}-2}, b l a_{\mathrm{CTX}-\mathrm{M}-8}, b l a_{\mathrm{CTX}-\mathrm{M}-14}$, and $b l a_{\mathrm{CTX}-\mathrm{M}-55}$ were recently reported [31]. Hence, our study and others indicate the presence and dissemination of clinically important beta-lactamases in E. coli in sheep, their products, and the abattoir environment, and the necessity for routine surveillance of these pathogens.

Moreover, ESBL E. coli from sheep and the abattoir environment carried AMR genes conferring resistance to Tetracyclines, Sulfonamides, Aminoglycosides, phenicols, Quinolones, Macrolides, Trimethoprim, and Lincosamide. AMR-associated point mutations at gyr $A$, $\operatorname{parC}$, and parE that confer resistance to fluoroquinolones and at $u h p T$ and $c y a A$ that confer resistance to Fosfomycin were detected in these pathogens [32]. From all detected AMR

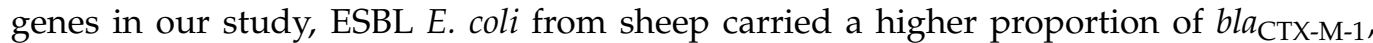
$b l a_{\mathrm{TEM}-1 \mathrm{~A}}$, floR, qnrB19, and sul2, while those from the environment carried a higher proportion of $b l a_{\mathrm{CTX}-\mathrm{M}-15}$ and $b l a_{\mathrm{TEM}-1 \mathrm{C}}$. Our study detected genotypic determinants of AMR in ESBL E. coli that were more diversified than in previous reports from cattle and retail meats in the U.S. [9] and sheep in Spain and Portugal [10]. The higher percentage of AMR genes in the sheep in our study could be due to inadequate biosecurity measures, including mixing of animals (sheep, goats, and cattle) from different farms and county fairs, sharing of contaminated feed and water from common sources at the abattoir resting area and prolonged time of duration for interaction, or sharing of AMR bacteria and the associated horizontal gene transfer between them [33]. Although our study did not evaluate these plausible reasons, it was reported that environmental samples from county fairs and livestock auction markets carried a higher level of Cephalosporin and fluoroquinolone-resistant E. coli than those from individual facilities for dairy cattle, equine, or companion animals [21]. At the study abattoir, sheep, goats, and cattle were allowed to roam around for a few hours to up to three days before slaughter. The abattoir operates year-round, receiving animals from different sources, which further increases the chance of introducing diversified genotypes of bacteria. We noticed that the abattoir routinely conducted proper cleaning and applied antiseptics on the lairage at the end of each slaughter day. However, the abattoir resting area was muddy and/or dusty, which might allow immediate contamination of the lairage. We detected a higher diversity of AMR genes in the abattoir environment and recovered a higher percentage of Salmonella and ESBL E. coli in abattoir environmental samples, which supports this observation (data not shown). Another contributing factor could be a large number of animals packed per waiting pens/cubicles as observed during the study. 
From the 19 different types of plasmids detected in our study, about 70\% of ESBL E. coli isolates carried two or more types. These were primarily incompatibility (Inc type) and colicinogenic (Col type) plasmids. Most plasmids detected in ESBL/AmpC E. coli were reported to be plasmid-mediated [10]. From all plasmids detected in this study, IncA/C, IncF, IncI1-Alpha, IncN, and IncH were previously found to be associated with MDR and commensal E. coli $[34,35]$. Combining all types of IncF plasmids (IncFIA, IncFIB, IncFIC, IncFIIpCoo, and IncFII), IncF was detected in more than two-thirds (76/113) of the ESBL E. coli isolates, indicating that they were the leading carriers of ESBL genes as previously noted [35]. IncR plasmids were the second abundant (57/113) types of plasmids in our study. IncR plasmid was described to carry genes belonging to many classes of antimicrobials, including beta-lactams and quinolones [35].

Multiple sequence types $(n=29)$ were found to harbor CTX-M-type ESBL genes in our study. From these, at least eight of the STs, namely, ST10, ST58, ST90, ST162, ST361, ST540, and ST744, were previously reported in ESBL E. coli from dairy cows [23] and ST10, ST58, ST398, and ST540 were reported from fluoroquinolone-resistant E. coli from retail meats (ground turkey and pork chops) in the U.S. [36]. However, this study did not detect major pandemic lineages such as ST131, ST393, ST69, ST95, and ST73 (Riley, 2014). The carbapenemase gene, $b l a_{\mathrm{NDM}-1}$ was not detected in our study. However, in our research, an isolate from feed belongs to ST101, associated with the New-Delhi metallo-beta-lactamase encoding gene $\left(b l a_{\mathrm{NDM}-1}\right)[37,38]$.

In this study, most of the isolates were phylogroups A (73/113) and B1 (31/113), followed by E (4/113), C (2/113), D (2/113), and CladeI (1/113), and all except phylogroup $\mathrm{C}$ were detected in isolates from sheep samples. Phylogroup A was detected at a higher proportion in isolates from all sample types except those from soil samples, where a higher proportion of phylogroup B1 was detected. ESBL E. coli isolates from cecal content had the most diversified phylogroups (A, B1, D, E, and CladeI). An abattoir-based study in Portugal indicated that $92.6 \%(50 / 54)$ of E. coli recovered from sheep were phylogroup A and B1 [39], the remaining two each from phylogroup B2 and D. However, the proportion of B1 was about twice the proportion of A1 in their study, contrasting the result in our study. Similarly, the predominance of phylogroups A and B1 in E. coli was reported in ruminants (cattle and sheep) in Turkey. In addition, they reported phylogroup D both from cattle and sheep but did not report other phylogroups [19]. Phylogroup B2 and D are considered pathogenic [40]. Two isolates in our study were phylogroup D.

Of the 38 different serotypes of ESBL E. coli detected in our study, one was O45, which is among the most common serogroups of non-STEC capable of causing disease in humans [41]. Among the identified serotypes, at least seven of them were considered noble serotypes by the EcoH database, including O5:H21, O9:H34, O10:H29, O22, or O32:H9, O24:H32, O31:H15, and O32:H10.

The phylogenetic analyses revealed that most of the unique sequence types tend to cluster around seasons but not around sample type or source of isolates. This may suggest close interaction between animals at the slaughter facility and the abattoir environment, facilitating the sharing of bacteria and AMR genes. Although only ST10 and ST398 were detected across all seasons and ST58 and ST2325 were detected in three seasons, these isolates were clonal, indicating persistence in the environment and animals throughout the year. This could be due to differences in bacterial fitness, previous environmental dissemination, and livestock farms and markets where the animals come from. It was interesting to see that these STs harbored diverse types of beta-lactamase genes. ST10 isolates harbored eight unique types of beta-lactamase genes (five CTX-M-types, AmpC type, and two TEM-types), ST58 and ST2325 harbored three CTX-M types, and the former had one TEM type beta-lactamase gene. However, isolates with ST398 harbored only bla $a_{\mathrm{CTX}-\mathrm{M}-32}$ and $b l a_{\mathrm{CARB}-2}$. This might need further investigation. A recent report indicated such fitness differences could be associated with plasmid-host adaptations [42].

Core genome phylogenetic analyses indicated that almost all types of beta-lactamase genes were scattered throughout the phylogenetic tree. Similar STs were detected in 
isolates recovered from both sheep and the environment. These may further indicate close interaction and mobile genetic transfer of acquired AMR genes between isolates from both sources. For example, six clonal ESBL E. coli isolates (O100:H32; ST10-A) that carried a combination of three beta-lactam genes were recovered from six different samples and detected in two seasons (fall and winter).

The study had limitations, as some important demographic information was not accessible such as the history of illnesses and antimicrobial use, geographical source of animals, history of transportation, dietary changes, and husbandry management. The study did not evaluate the possible contribution of cattle and goats at the same facility in the dissemination of ESBL E. coli and AMR genes. Additionally, we did not look into the effect of transportation and abattoir environment in acquiring AMR genes and their dissemination to sheep and their products.

In conclusion, this is the first comprehensive report of AMR determinants in ESBL E. coli from sheep and their abattoir environment in the U.S. Sheep are a significant reservoir of ESBL E. coli and AMR determinants, and this study notably indicated close interaction between ESBL E. coli from sheep and their abattoir environment. The abattoir environment might have played a significant role in the persistence and dissemination of these pathogens. We propose routine AMR surveillance of sheep and their products to prevent future public health risks.

\section{Materials and Methods}

\subsection{Study Design and Bacterial Isolates}

From the pool of ESBL E. coli isolates recovered during a serial cross-sectional study conducted between March 2019 and February 2020, we selected 113 ESBL E. coli isolates for molecular characterization of AMR determinants. The selected isolates were recovered from sheep samples $(n=65)$ and abattoir environment samples $(n=48)$. Break down of samples collected and sampling methodology are described in Table S4. Sources of ESBL E. coli isolates from sheep were carcass swabs $(n=10)$, feces $(n=28)$, cecal contents $(n=20)$, and abattoir resting area feces $(n=7)$, and those from the abattoir environment were lairage swabs $(n=21)$, soil $(n=10)$, feed $(n=8)$ and water $(n=9)$. The abattoir slaughtered sheep, goats, and cattle on a routine basis. These animals were allowed to roam around from a few hours to up to three days and share feed and water from the same troughs. Information on antimicrobial use, husbandry, and demography was not accessible to us. ESBL E. coli isolates were selected based on their AMR profile, the season of sampling, and the type (source) of samples. Confirmation of ESBL production was conducted using double-disk diffusion methods following Clinical and Laboratory Standards Institute (CLSI) guidelines [43]. Confirmed ESBL E. coli isolates had a zone of inhibition of $\geq 5 \mathrm{~mm}$ for either Cefotaxime or Ceftazidime with Clavulanic acid compared to without Clavulanic acid. The isolates' antimicrobial susceptibility was determined by broth microdilution methods using the NARMS Sensititre 14 antimicrobial drug panel. Data interpretation and categorization into susceptible, intermediate, and resistant were determined based on resistance breakpoints recommended by the CLSI of the U.S. [44,45], except for Streptomycin, which was determined based on resistance breakpoints recommended by the NARMS [46]. The number and percent resistance of ESBL E. coli isolates for the fourteen antimicrobials in the NARMS Sensititre panel are presented in Table 1.

\subsection{Whole-Genome Sequencing}

The template DNA for whole-genome sequencing (WGS) was extracted from an overnight culture of all selected E. coli isolates using the Qiagen DNeasy PowerLyser Microbial Kit following the manufacturer's protocol. The purified DNA was quantified using a NanoDrop 2000 Spectrophotometer (Thermo Scientific, USA). The sequencing DNA library was prepared using the Nextera DNA Flex Library preparation kit (Illumina, San Diego, CA, USA) as previously described [47]. A Qubit 3.0 Fluorometer (ThermoFisher Scientific, Waltham, MA, USA) was used to quantify the library prep. WGS was performed 
on Illumina MiSeq with $300 \mathrm{bp}$ paired-end reads. The average number of assembled contigs per sample was 96 (range 40 to 254), the average N50 was $201 \mathrm{~kb}$ (range $79 \mathrm{~kb}$ to $672 \mathrm{~kb}$ ), and the total assembly length was 4.6 to 5.6 megabases $(\mathrm{Mb})$.

Sequences were assembled using SPAdes 3.14.1 [48] and annotated with PROKKA [49] at default settings. The quality of genome assembly was assessed using Quast [50]. AMR genes, plasmids, and virulence genes were identified by the ABRicate pipeline, as previously described [51]. ABRicate included multiple databases including NCBI, CARD, ARGANNOT, ResFinder, MEGARES, EcOH, PlasmidFinder, Ecoli_VF, and VFDB. Reported AMR genes and plasmids were primarily based on summary results from ResFinder [52] and PlasmidFinder [53] databases of ABRicate program, respectively. The NCBI's AMRfinderPlus database (version 3.10.5, Bethesda, MD, USA) [54] was used for the detection of AMR-associated point mutations. A gene was considered present in the assembled genome of an isolate when there was $90 \%$ nucleotide identity and $80 \%$ coverage of length match with the specific gene in the database. In silico serotyping of the E. coli isolates was carried out using the $\mathrm{EcOH}$ database [55] in the ABRicate program, whereas E. coli isolates were phylogrouped using ClermonTyping [56], which divides them into seven main phylogroups termed A, B1, B2, C, D, E, and F.

\subsection{Phylogenetic Analysis}

Prokka (version 1.14.6) was used to annotate isolate genomes [49], and pan-genome analyses were conducted using Roary (version 3.13.0) with a minimum percentage identity for blastp of 95\% [57]. Within Roary, MAFFT [58] was used to create a core genome alignment of genes present in $99 \%$ of the isolates. The core genome alignment was used to generate a phylogenetic tree on RaxMLGUI2.0 (RaxML-NG version 1.0.1) [59]. The bestfitting model identified was general time-reversible substitution with a Gamma rate of heterogeneity and a proportion of invariable sites estimate (GTR + I + G) and used to generate the maximum-likelihood phylogenetic tree with 500 bootstrap replicates. The phylogenetic tree was visualized and annotated using iTOL version 6.3 (https:/ / itol.embl.de/itol.cgi; accessed on 19 July 2021) [60].

\subsection{Statistical Analyses}

The frequency of detection of AMR genes in ESBL E. coli from sheep and the abattoir environment was estimated. Parameters of central tendency and dispersion, bar diagrams, contingency tables, and simple proportions were obtained. The statistical significance was set at the alpha value of $\leq 0.05$. Statistical analyses were performed using SAS version 9.4 (SAS Institute Inc., Cary, NC, USA).

Supplementary Materials: The following are available online at https:/ / www.mdpi.com/article/10 .3390 / pathogens10111480/s1, Table S1: Phenotypic AMR profiles, AMR genes, and AMR associated point mutations detected in ESBL E. coli isolates $(\mathrm{n}=113)$ from sheep and abattoir environment, Table S2: Frequency of AMR determinants detected in ESBL E. coli isolates $(n=113)$ among sample sources and seasons, Table S3: Number and percentage of AMR genes other than beta-lactamases in ESBL E. coli isolates $(\mathrm{n}=113)$ from sheep and abattoir environment. Table S4: Sampling methodology

Author Contributions: Conceptualization, N.A.A., P.J.F.C., S.T. and S.K.; methodology, N.A.A., P.J.F.C., S.T., S.K. and L.H.; software, N.A.A., M.C., L.H.; validation, P.J.F.C., S.T., M.C. and S.K.; formal analysis, N.A.A. and M.C.; investigation, N.A.A., S.K.; resources, S.K. and L.H.; data curation, N.A.A. and L.H.; writing—original draft preparation, N.A.A.; writing—review and editing N.A.A., P.J.F.C., S.T., S.K., M.C., D.F., W.G. and A.A.-K.; visualization, N.A.A.; supervision, P.J.F.C. and S.T.; project administration, P.J.F.C. and S.K.; funding acquisition, P.J.F.C. and S.T. All authors have read and agreed to the published version of the manuscript.

Funding: This research was funded by North Carolina State University. The whole-genome sequencing work is supported by the National Institutes of Health/Food and Drug Administration under award number 5U 18FD006194-02.

Institutional Review Board Statement: Not applicable. 
Informed Consent Statement: Not applicable.

Data Availability Statement: Raw Illumina WGS reads were submitted to the National Center for Biotechnology Information (NCBI) database and all data can be found under BioProject accession number PRJNA293225.

Acknowledgments: The authors would like to thank the College of Veterinary Medicine of North Carolina State University and GenomeTrakr Project for their funding of the entire study and wholegenome sequencing of study isolates. We are also grateful to the staff and team members of both Cray-Keelara and Thakur laboratories. We also thank the abattoir owner and staff for their cooperation during sampling. We also acknowledge input from Dawn Hull and Hanna Berman on bioinformatics analyses.

Conflicts of Interest: The authors declare no conflict of interest.

\section{References}

1. CDC. Antibiotic Resistance Threats in the United States; Centers for Disease Control and Prevention, U.S. Department of Health and Human Services: Atlanta, GA, USA, 2019. Available online: https://www.cdc.gov/drugresistance/pdf/threats-report/2019-arthreats-report-508.pdf (accessed on 23 September 2021).

2. Diekema, D.J.; Hsueh, P.-R.; Mendes, R.E.; Pfaller, M.A.; Rolston, K.V.; Sader, H.; Jones, R.N. The Microbiology of Bloodstream Infection: 20-Year Trends from the SENTRY Antimicrobial Surveillance Program. Antimicrob. Agents Chemother. 2019, 63, e00355-19. [CrossRef]

3. Frye, J.G.; Jackson, C.R. Genetic mechanisms of antimicrobial resistance identified in Salmonella enterica, Escherichia coli, and Enteroccocus spp. isolated from U.S. food animals. Front. Microbiol. 2013, 4, 135. [CrossRef]

4. Poole, T.; Callaway, T.; Norman, K.; Scott, H.; Loneragan, G.; Ison, S.; Beier, R.; Harhay, D.; Norby, B.; Nisbet, D. Transferability of antimicrobial resistance from multidrug-resistant Escherichia coli isolated from cattle in the USA to E. coli and Salmonella Newport recipients. J. Glob. Antimicrob. Resist. 2017, 11, 123-132. [CrossRef] [PubMed]

5. Lewis, J.S.; Herrera, M.; Wickes, B.; Patterson, J.E.; Jorgensen, J.H. First Report of the Emergence of CTX-M-Type ExtendedSpectrum $\beta$-Lactamases (ESBLs) as the Predominant ESBL Isolated in a U.S. Health Care System. Antimicrob. Agents Chemother. 2007, 51, 4015-4021. [CrossRef]

6. Wang, G.; Huang, T.; Surendraiah, P.K.M.; Wang, K.; Komal, R.; Zhuge, J.; Chern, C.-R.; Kryszuk, A.A.; King, C.; Wormser, G.P. CTX-M $\beta$-Lactamase-producing Klebsiella pneumoniaein Suburban New York City, New York, USA. Emerg. Infect. Dis. 2013, 19, 1803-1810. [CrossRef] [PubMed]

7. Chen, L.F.; Freeman, J.T.; Nicholson, B.; Keiger, A.; Lancaster, S.; Joyce, M.; Woods, C.W.; Cook, E.; Adcock, L.; Louis, S.; et al. Widespread Dissemination of CTX-M-15 Genotype Extended-Spectrum- $\beta$-Lactamase-Producing Enterobacteriaceae among Patients Presenting to Community Hospitals in the Southeastern United States. Antimicrob. Agents Chemother. 2013, 58, 1200-1202. [CrossRef] [PubMed]

8. Wittum, T.E.; Mollenkopf, D.F.; Daniels, J.B.; Parkinson, A.E.; Mathews, J.L.; Fry, P.R. CTX-M-Type Extended-Spectrum $\beta$ Lactamases Present in Escherichia coli from the Feces of Cattle in Ohio, United States. Foodborne Pathog Dis. 2010, 7, 1575-1579. [CrossRef]

9. Tadesse, D.A.; Li, C.; Mukherjee, S.; Hsu, C.-H.; Bodeis Jones, S.; Gaines, S.A.; Kabera, C.; Loneragan, G.H.; Torrence, M.; Harhay, D.M.; et al. Whole-Genome Sequence Analysis of CTX-M Containing Escherichia coli Isolates from Retail Meats and Cattle in the United States. Microb. Drug Resist. 2018, 24, 939-948. [CrossRef]

10. Tello, M.; Ocejo, M.; Oporto, B.; Hurtado, A. Prevalence of Cefotaxime-Resistant Escherichia coli Isolates from Healthy Cattle and Sheep in Northern Spain: Phenotypic and Genome-Based Characterization of Antimicrobial Susceptibility. Appl. Environ. Microbiol. 2020, 86, e00742-20. [CrossRef] [PubMed]

11. Ye, Q.; Wu, Q.; Zhang, S.; Zhang, J.; Yang, G.; Wang, J.; Xue, L.; Chen, M. Characterization of Extended-Spectrum $\beta$-LactamaseProducing Enterobacteriaceae from Retail Food in China. Front. Microbiol. 2018, 9, 1709. [CrossRef] [PubMed]

12. Liu, X.; Thungrat, K.; Boothe, D.M. Occurrence of OXA-48 Carbapenemase and Other $\beta$-Lactamase Genes in ESBL-Producing Multidrug Resistant Escherichia coli from Dogs and Cats in the United States, 2009-2013. Front. Microbiol. 2016, 7, 1057. [CrossRef]

13. Seni, J.; Falgenhauer, L.; Simeo, N.; Mirambo, M.M.; Imirzalioglu, C.; Matee, M.; Rweyemamu, M.; Chakraborty, T.; Mshana, S.E. Multiple ESBL-Producing Escherichia coli Sequence Types Carrying Quinolone and Aminoglycoside Resistance Genes Circulating in Companion and Domestic Farm Animals in Mwanza, Tanzania, Harbor Commonly Occurring Plasmids. Front. Microbiol. 2016, 7, 142. [CrossRef] [PubMed]

14. Önen, S.P.; Aslantaş, Ö.; Yılmaz, E.; Kürekci, C. Prevalence of $\beta$-Lactamase Producing Escherichia colifrom Retail Meat in Turkey. J. Food Sci. 2015, 80, M2023-M2029. [CrossRef] [PubMed]

15. Santman-Berends, I.; Gonggrijp, M.; Hage, J.; Heuvelink, A.; Velthuis, A.; Lam, T.; Van Schaik, G. Prevalence and risk factors for extended-spectrum $\beta$-lactamase or AmpC-producing Escherichia coli in organic dairy herds in the Netherlands. J. Dairy Sci. 2017, 100, 562-571. [CrossRef] [PubMed] 
16. Lee, S.; Mir, R.A.; Park, S.H.; Kim, D.; Kim, H.-Y.; Boughton, R.K., Jr.; Jeong, K.C. Prevalence of extended-spectrum $\beta$-lactamases in the local farm environment and livestock: Challenges to mitigate antimicrobial resistance. Crit. Rev. Microbiol. 2020, 46, 1-14. [CrossRef] [PubMed]

17. Geser, N.; Stephan, R.; Hächler, H. Occurrence and characteristics of extended-spectrum $\beta$-lactamase (ESBL) producing Enterobacteriaceae in food producing animals, minced meat and raw milk. BMC Vet. Res. 2012, 8, 21. [CrossRef]

18. Gozi, K.S.; Froes, J.R.; Ajude, L.P.T.D.; Da Silva, C.R.; Baptista, R.S.; Peiró, J.R.; Marinho, M.; Mendes, L.C.N.; Nogueira, M.C.L.; Casella, T. Dissemination of Multidrug-Resistant Commensal Escherichia coli in Feedlot Lambs in Southeastern Brazil. Front. Microbiol. 2019, 10, 1394. [CrossRef]

19. Pehlivanoglu, F.; Turutoglu, H.; Ozturk, D.; Yardimci, H. Molecular Characterization of ESBL-Producing Escherichia Coli Isolated from Healthy Cattle and Sheep. Acta Vet. 2016, 66, 520-533. [CrossRef]

20. Poirel, L.; Nordmann, P.; Ducroz, S.; Boulouis, H.-J.; Arné, P.; Millemann, Y. Extended-Spectrum $\beta$-Lactamase CTX-M-15Producing Klebsiella pneumoniae of Sequence Type ST274 in Companion Animals. Antimicrob. Agents Chemother. 2013, 57, 2372-2375. [CrossRef]

21. Adams, R.J.; Kim, S.S.; Mollenkopf, D.F.; Mathys, D.A.; Schuenemann, G.M.; Daniels, J.B.; Wittum, T.E. Antimicrobial-resistant Enterobacteriaceae recovered from companion animal and livestock environments. Zoonoses Public Health 2018, 65, 519-527. [CrossRef]

22. Talan, D.A.; Takhar, S.S.; Krishnadasan, A.; Abrahamian, F.M.; Mower, W.R.; Moran, G.J. Fluoroquinolone-Resistant and Extended-Spectrum $\beta$-Lactamase- Producing Escherichia coli Infections in Patients with Pyelonephritis, United States. Emerg Infect Dis. 2017, 22, 1594-1603.

23. Afema, J.A.; Ahmed, S.; Besser, T.E.; Jones, L.P.; Sischo, W.M.; Davis, M.A. Molecular Epidemiology of Dairy Cattle-Associated Escherichia coli Carrying bla CTX-M Genes in Washington State. Appl. Environ. Microbiol. 2018, 84, e02430-17. [CrossRef] [PubMed]

24. Dierikx, C.M.; Van Duijkeren, E.; Schoormans, A.H.W.; Van Essen-Zandbergen, A.; Veldman, K.; Kant, A.; Huijsdens, X.W.; Van Der Zwaluw, K.; Wagenaar, J.A.; Mevius, D.J. Occurrence and characteristics of extended-spectrum- $\beta$-lactamase- and AmpC-producing clinical isolates derived from companion animals and horses. J. Antimicrob. Chemother. 2012, 67, 1368-1374 [CrossRef] [PubMed]

25. Castanheira, M.; Simner, P.J.; Bradford, A.P. Extended-spectrum $\beta$-lactamases: An update on their characteristics, epidemiology and detection. JAC-Antimicrob. Resist. 2021, 3, dlab092. [CrossRef]

26. Robberts, L.; Kohner, P.C.; Patel, R. Unreliable Extended-Spectrum $\beta$-Lactamase Detection in the Presence of Plasmid-Mediated AmpC in Escherichia coli Clinical Isolates. J. Clin. Microbiol. 2009, 47, 358-361. [CrossRef]

27. Poulou, A.; Grivakou, E.; Vrioni, G.; Koumaki, V.; Pittaras, T.; Pournaras, S.; Tsakris, A. Modified CLSI Extended-Spectrum Lactamase (ESBL) Confirmatory Test for Phenotypic Detection of ESBLs among Enterobacteriaceae Producing Various -Lactamases. J. Clin. Microbiol. 2014, 52, 1483-1489. [CrossRef]

28. Zankari, E.; Hasman, H.; Kaas, R.S.; Seyfarth, A.M.; Agersø, Y.; Lund, O.; Larsen, M.V.; Aarestrup, F. Genotyping using wholegenome sequencing is a realistic alternative to surveillance based on phenotypic antimicrobial susceptibility testing. J. Antimicrob. Chemother. 2012, 68, 771-777. [CrossRef]

29. Castanheira, M.; Mendes, R.E.; Rhomberg, P.R.; Jones, R.N. Rapid Emergence ofblaCTX-MAmong Enterobacteriaceae in U.S. Medical Centers: Molecular Evaluation from the MYSTIC Program (2007). Microb. Drug Resist. 2008, 14, 211-216. [CrossRef]

30. McGann, P.; Snesrud, E.; Maybank, R.; Corey, B.; Ong, A.C.; Clifford, R.; Hinkle, M.; Whitman, T.; Lesho, E.; Schaecher, K.E. Escherichia coli Harboring mcr-1 and bla CTX-M on a Novel IncF Plasmid: First Report of mcr-1 in the United States. Antimicrob. Agents Chemother. 2016, 60, 4420-4421. [CrossRef]

31. Gozi, K.S.; Ajude, L.P.T.D.; Barroso, M.D.V.; Da Silva, C.R.; Peiró, J.R.; Mendes, L.C.N.; Nogueira, M.C.L.; Casella, T. Potentially Pathogenic Multidrug-Resistant Escherichia coli in Lamb Meat. Microb. Drug Resist. 2021, 27. [CrossRef]

32. Silver, L.L. Fosfomycin: Mechanism and Resistance. Cold Spring Harb. Perspect. Med. 2017, 7, a025262. [CrossRef]

33. Lorenz, M.; Wackernagel, W.; Håvarstein, L.S. Bacterial Gene Transfer by Natural Genetic Transformation. APMIS 1998, 106, 43-46. [CrossRef]

34. Johnson, T.; Logue, C.M.; Johnson, J.R.; Kuskowski, M.A.; Sherwood, J.S.; Barnes, H.J.; Debroy, C.; Wannemuehler, Y.M.; ObataYasuoka, M.; Spanjaard, L.; et al. Associations Between Multidrug Resistance, Plasmid Content, and Virulence Potential Among Extraintestinal Pathogenic and CommensalEscherichia colifrom Humans and Poultry. Foodborne Pathog. Dis. 2012, 9, 37-46. [CrossRef] [PubMed]

35. Rozwandowicz, M.; Brouwer, M.S.M.; Fischer, J.; Wagenaar, A.J.; Gonzalez-Zorn, B.; Guerra, B.; Mevius, D.J.; Hordijk, J. Plasmids carrying antimicrobial resistance genes in Enterobacteriaceae. J. Antimicrob. Chemother. 2018, 73, 1121-1137. [CrossRef] [PubMed]

36. Tyson, G.H.; Li, C.; Hsu, C.-H.; Bodeis-Jones, S.; McDermott, P.F. Diverse Fluoroquinolone Resistance Plasmids from Retail Meat E. coli in the United States. Front. Microbiol. 2019, 10, 2826. [CrossRef] [PubMed]

37. Toleman, M.A.; Bugert, J.J.; Nizam, S.A. Extensively Drug-Resistant New Delhi Metallo- $\beta$-Lactamase-Encoding Bacteria in the Environment, Dhaka, Bangladesh, 2012. Emerg. Infect. Dis. 2015, 21, 1027-1030. [CrossRef]

38. Ranjan, A.; Shaik, S.; Mondal, A.; Nandanwar, N.; Hussain, A.; Semmler, T.; Kumar, N.; Tiwari, S.K.; Jadhav, S.; Wieler, L.H.; et al. Molecular Epidemiology and Genome Dynamics of New Delhi Metallo- $\beta$-Lactamase-Producing Extraintestinal Pathogenic Escherichia coli Strains from India. Antimicrob. Agents Chemother. 2016, 60, 6795-6805. [CrossRef] 
39. Ramos, S.; Silva, N.; Caniça, M.; Capelo-Martinez, J.L.; Brito, F.; Igrejas, G.; Poeta, P. High prevalence of antimicrobial-resistant Escherichia coli from animals at slaughter: A food safety risk. J. Sci. Food Agric. 2012, 93, 517-526. [CrossRef]

40. Clermont, O.; Bonacorsi, S.; Bingen, E. Rapid and Simple Determination of the Escherichia coli Phylogenetic Group. Appl. Environ. Microbiol. 2000, 66, 4555-4558. [CrossRef]

41. Brooks, J.T.; Sowers, E.G.; Wells, J.G.; Greene, K.D.; Griffin, P.M.; Hoekstra, R.M.; Strockbine, N.A. Non-O157 Shiga ToxinProducingEscherichia coliInfections in the United States, 1983-2002. J. Infect. Dis. 2005, 192, 1422-1429. [CrossRef]

42. Pietsch, M.; Fuchs, S.; Werner, G. Genome-Based Analyses of Fitness Effects and Compensatory Changes Associated with

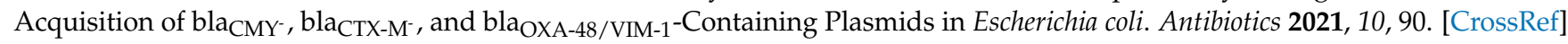

43. CLSI. Standards for Antimicrobial Susceptibility Testing. Performance Standards for Antimicrobial Susceptibility Testing, 27th ed.; CLSI supplement M100; Clinical and Laboratory Standards Institute: Wayne, PA, USA, 2017.

44. CLSI. EM100 Connect-CLSI M100 ED31:2021. 2021 [cited 23 Oct 2021]. Available online: http:/ / em100.edaptivedocs.net/GetDoc. aspx?doc=CLSIM100ED31:2021\&sbssok=CLSIM100ED31:2021TABLE2A\&format=HTML\#CLSIM100ED31:2021TABLE2A (accessed on 23 October 2021).

45. CLSI. VET01S Connect-CLSI VET01S ED5:2020. 2020. Available online: http://clsivet.org/GetDoc.aspx?doc=CLSIVET01SED5: 2020\&sbssok=CLSIVET01SED5:2020TABLE2A\&format=HTML\&hl=Ceftiofur (accessed on 23 October 2021).

46. CDC. Antibiotics Tested by NARMS I NARMS I CDC. Available online: https://www.cdc.gov/narms/antibiotics-tested.html (accessed on 19 August 2021).

47. CDC. Laboratory Standard Operating Procedure for PulseNet Nextera XT Library Prep and Run Setup for the Illumina MiSeq; Centers for Disease Control and Prevention: Atlanta, GA, USA, 2016; Volume PNL32, pp. 1-46. Available online: https://www.cdc.gov/ pulsenet/pdf/pnl32-miseq-nextera-xt.pdf (accessed on 11 July 2018).

48. Bankevich, A.; Nurk, S.; Antipov, D.; Gurevich, A.A.; Dvorkin, M.; Kulikov, A.S.; Lesin, V.M.; Nikolenko, S.I.; Pham, S.; Prjibelski, A.D.; et al. SPAdes: A New Genome Assembly Algorithm and Its Applications to Single-Cell Sequencing. J. Comput. Biol. 2012, 19, 455-477. [CrossRef] [PubMed]

49. Seemann, T. Prokka: Rapid Prokaryotic Genome Annotation. Bioinformatics 2014, 30, 2068-2069. [CrossRef] [PubMed]

50. Gurevich, A.; Saveliev, V.; Vyahhi, N.; Tesler, G. QUAST: Quality assessment tool for genome assemblies. Bioinformatics 2013, 29, 1072-1075. [CrossRef] [PubMed]

51. Hull, D.M.; Harrell, E.; van Vliet, A.H.M.; Correa, M.; Thakur, S. Antimicrobial resistance and interspecies gene transfer in Campylobacter coli and Campylobacter jejuni isolated from food animals, poultry processing, and retail meat in North Carolina, 2018-2019. PLoS ONE 2021, 16, e0246571. [CrossRef]

52. Zankari, E.; Hasman, H.; Cosentino, S.; Vestergaard, M.; Rasmussen, S.; Lund, O.; Aarestrup, F.M.; Larsen, M.V. Identification of acquired antimicrobial resistance genes. J. Antimicrob. Chemother. 2012, 67, 2640-2644. [CrossRef] [PubMed]

53. Carattoli, A.; Zankari, E.; García-Fernández, A.; Larsen, M.V.; Lund, O.; Villa, L.; Aarestrup, F.M.; Hasman, H. In Silico Detection and Typing of Plasmids using PlasmidFinder and Plasmid Multilocus Sequence Typing. Antimicrob. Agents Chemother. 2014, 58, 3895-3903. [CrossRef]

54. Feldgarden, M.; Brover, V.; Haft, D.H.; Prasad, A.B.; Slotta, D.J.; Tolstoy, I.; Tyson, G.H.; Zhao, S.; Hsu, C.-H.; McDermott, P.F.; et al. Validating the AMRFinder Tool and Resistance Gene Database by Using Antimicrobial Resistance Genotype-Phenotype Correlations in a Collection of Isolates. Antimicrob. Agents Chemother. 2019, 63, e00483-19. [CrossRef] [PubMed]

55. Ingle, D.J.; Valcanis, M.; Kuzevski, A.; Tauschek, M.; Inouye, M.; Stinear, T.; Levine, M.M.; Robins-Browne, R.M.; Holt, K.E. In silico serotyping of E. coli from short read data identifies limited novel O-loci but extensive diversity of O:H serotype combinations within and between pathogenic lineages. Microb. Genom. 2016, 2, e000064. [CrossRef]

56. Beghain, J.; Bridier-Nahmias, A.; Le Nagard, H.; Denamur, E.; Clermont, O. ClermonTyping: An easy-to-use and accurate in silico method for Escherichia genus strain phylotyping. Microb. Genom. 2018, 4, e000192. [CrossRef]

57. Page, A.J.; Cummins, C.A.; Hunt, M.; Wong, V.K.; Reuter, S.; Holden, M.T.G.; Fookes, M.; Falush, D.; Keane, J.A.; Parkhill, J. Roary: Rapid large-scale prokaryote pan genome analysis. Bioinformatics 2015, 31, 3691-3693. [CrossRef]

58. Katoh, K.; Standley, D.M. MAFFT Multiple Sequence Alignment Software Version 7: Improvements in Performance and Usability. Mol. Biol. Evol. 2013, 30, 772-780. [CrossRef] [PubMed]

59. Edler, D.; Klein, J.; Antonelli, A.; Silvestro, D. raxmlGUI 2.0: A graphical interface and toolkit for phylogenetic analyses using RAxML. Methods Ecol. Evol. 2020, 12, 373-377. [CrossRef]

60. Letunic, I.; Bork, P. Interactive tree of life (iTOL) v3: An online tool for the display and annotation of phylogenetic and other trees. Nucleic Acids Res. 2016, 44, W242-W245. [CrossRef] [PubMed] 